\title{
SOCIOLOGICAL STUDY OF THE IMAGES OF THE NEIGHBORING COUNTRIES: RUSSIAN STUDENT YOUTH STEREOTYPES, AND THEIR CONTEXTUAL FRAMES ${ }^{2}$
}

ABSTRACT. The article identifies three basic 'dimensions' of the youth social mood. The first dimension is formed by a set of various cognitive, affective and behavioral orientations (and the patriotic mood is an integral part of this complex). The second dimension is formed by a set of estimates of the macro-social context of life in one's country. The third dimension is constituted by geopolitical awareness, i.e. the images of the neighboring countries. All three dimensions are difficult to measure due to the multiplicity of their conceptualization frames and excessive connotations of the basic terminology. The author provides an overview of the results of a series of surveys conducted in 2009-2013 on the samples of Moscow students by the Sociological Laboratory of the Peoples' Friendship University of Russia to show what data we can obtain with the help of qualitative approach in 'measuring' these dimensions of the youth worldview and social mood, especially in identifying the common images of the neighboring countries (on the example of China, Kazakhstan and Serbia). The author focuses on technical and substantial details of the surveys, and concludes with recognizing the necessity of revealing social representations and stereotypes of public opinion in cross-cultural and comparative perspectives.

KEY WORDS: Russian students, stereotypes, images, neighboring countries, social and patriotic mood, sociological measurement, survey, cross-cultural and comparative perspective, 2009-2013.

irina.trotsuk@yandex.ru

The research was supported by the Russian Foundation for Humanities. Grant №15-03-00573.

Рад је примљен 18. новембра 2015, а прихваћен за објављивање на састанку Редакције 3борника одржаном 1. априла 2016. 
In recent years, Russian scientists and journalists increasingly note the emergence and stabilization of the following tendencies: on one hand, there is a visible government intervention in the private lives under the banner of struggle for the moral health of nation, for the welfare of younger generations, for the traditional family, religious values, etc. On the other hand, there is an obvious growth of geopolitical awareness among Russians of all ages supported by the government practical measures to increase the level of patriotism in the society at all costs. At the same time, there are also manifestations of a significant reduction of the state's presence and regulatory impact in a number of industries that used to be priority areas of public support, together with the participation of citizens in a variety of volunteer events and structures to offset the indifference of state regulatory and bureaucratic apparatus to the fate of individuals and entire local communities. Nevertheless, such manifestations seem to develop 'in parallel' with the growth of geopolitical awareness and hurray-patriotic mood, while all trends are formed on the background of the general social indifference, which in the youth segment of the population turns into political apathy.

Allegations of political indifference of Russians are justified. As the results of many opinion polls show, since 2010, the share of Russians that openly admit they do not understand the politics has been about $50 \%$ with no significant changes in the direction of decreasing or increasing, while the percentage of those for whom the politics is depressing has grown from 47\% to 59\% (Politics depresses Russians, 2013) ${ }^{3}$. The reasons are predictable: about $80 \%$ of Russians believe that "politicians are interested only in obtaining or retaining power but not in meeting the voters' needs" (such wording is usually used in the questionnaires - respondents are asked to express the degree of agreement or disagreement with it).

However, the Russian government makes titanic efforts (at least announces such intentions) to 'hold' citizens in all senses of the word. On one hand, the political discourse constantly focuses on the demographic decline and out-migration. According to sociological data, in recent years the stable figure of $20 \%-22 \%$ of Russians have expressed a desire to leave the country, in $201345 \%$ of them were students, and the main motive for migration is the desire to arrange one's future, but the percentage of those taking real steps

3 Hereafter I refer to the data of 2013-2014 to contextualize properly the empirical data of a number of surveys conducted on the samples of Moscow students a little earlier or at the same period. 
to leave the country is about $1 \%$ (Emigration of the Putin era, 2013). Although the scale of intellectual migration from Russia is comparable to Europe and America, Russia lacks the reverse flow, which determines the "brain drain" and "creative class escape" (Florida, 2002; 2005).

On the other hand, the Russian state attempts to solve the demographic and out-migration problems by forcing 'jingoistic rhetoric' and introducing large-scale programs of 'upbringing real patriots'. Russian leaders postulate as one of the key tasks of the educational system 'teaching' patriotism to overcome the distrust of citizens to public authorities, to reduce the separatist sentiments and restrain the globalization trends in demography and migration. The first state program "Patriotic Education of Citizens of the Russian Federation" (2001-2005) aimed at developing the patriotic education and civil consciousness. The second program (2006-2010) sought to massification of patriotic consciousness as the basis of the spiritual unity of the country relying on the federal and regional institutes of patriotic education of younger generations created in the previous years. The third program (2011-2015) was to contribute to the destruction of extremism and to guarantee the political stability by providing the legal basis for the patriotic education and developing 'patriotic professional training'. One of the last steps in this direction that received the widest media coverage was a proposal of V. Putin to develop a common history textbook for high school, which would show "the single continuous logic of Russian history", "the fate of Russia as a union of different peoples, traditions and cultures". The current state program of the patriotic education (2016-2020) is an updated version of earlier programs developed to maintain "the formation of patriotic consciousness of Russian citizens on the basis of innovative technologies... through the joint efforts of government agencies and civil society".

Such a long introduction was necessary to contextualize the results of a series of surveys conducted in 2009-2013 on the samples of Moscow students by the Sociological Laboratory of the Peoples' Friendship University of Russia. There is no need to specify the particular years the data were collected, because until 2014, when our last (for today ${ }^{4}$ ) survey took place, the distribution of answers remained largely unchanged. For instance, every second

4 Today the Sociological Laboratory is working on a new series of the repeated surveys to check changes in the Russian student youth worldview in a new geopolitical and socio-economic situation. 
student agreed with the Russian government in that patriotism should be 'taught'; every fourth believed that patriotism must emerge spontaneously not to become an imposed pseudo-value, every third suggested combining spontaneous and purposeful ways of forming the patriotic mood. However, in assessing the current situation in Russia the students claimed that the government and the president rather spoke a lot about strengthening the patriotic mood than took adequate and effective steps to form such in some evident and understandable way.

There are several obvious 'dimensions' of the social mood: the first is formed by a set of cognitive, affective and behavioral orientations; the second - by estimates of macro-social context of life in the country; the third - by geopolitical awareness, i.e. images of the neighboring countries, which extend the boundaries of one's world beyond one's country. All three dimensions are difficult to measure due to the multiplicity of conceptualization frames and excessive connotations of the basic terminology. For instance, the word 'patriotism' seem to be clear as recorded in dictionaries - a "love of one's country, fatherland", respectively a patriot is a "lover of the fatherland, zealous for the good of it" (Dal', 1978, p. 24). However, patriotism allows contradictory interpretations in the context of a particular political situation and ideology, and in the old and present history of Russia almost every public figure expressed his attitude to patriotism in the fierce debates with adherents of opposite conceptual, functional or value interpretation of patriotism.

In Soviet times, the concept of patriotism had a coherent supraethnic definition, but since the early 1990s it had acquired negative connotations, primarily because previously identical concepts of homeland and the state got separated: the former caused warm emotions as the native land, feelings of the pride in the language, history, science and culture; the latter associated with the bureaucratic system, manipulating the concept of patriotism to 'force' the people to perceive the state as a homeland, to pay taxes and to remain committed to the values that had lost significance under the new market economy and ignorant state-machine. About $65 \%$ of Russians believed that the authorities in Russia had changed greatly compared with the Soviet period; those who saw principal differences between Russian and Soviet authorities name as basic the refusal to care about ordinary people, the pursuit of their own interests, and inability to cope with the problems of the country. On one hand, every fourth respondent acknowledged that theRus- 
sian government had established good relations with the West, every fifth thought that it had done much for Russia's status as a reputable country; on the other hand, every other fifth believed that the government did not manage to make Russia respected worldwide.

Since the early 2000 s the public opinion polls have shown a steady increase in the number of respondents who consider themselves patriots - the figure had stabilized in the mid-2000s and by 2010 reached $84 \%$, although the majority of 'patriots' were residents of the two major Russian cities (Moscow and SaintPetersburg) and the elderly (88\%) (New Russian patriotism, 2014). Our surveys on the samples of Moscow students showed that nearly half of the respondents considered themselves patriots; every third student found it difficult to identify oneself in terms of patriotism mainly due to the unacceptability of such an unambiguous selfidentification. Nevertheless, the majority of students took pride in the historical past of the country, its natural resources, cultural heritage and sports achievements. The set of 'objects' of pride indicates a dilution of the concepts 'homeland' and 'state' in the youth outlook: common 'objects' of shame relate to the activities of government institutions - the state of the economy and social sphere, respect for human rights and freedoms, activities of the state bodies in general and the standards of living of the population in particular.

The interpretation of patriotism as a love of country was confirmed by the confidence of respondents that there is always an obvious growth of patriotism in the periods of wars, revolutions and radical political upheavals (more than $70 \%$ ), but not in a situation of extreme aggravation of social contradictions (every fourth), therefore they considered the Victory Day the most patriotic national holiday (about 90\%). However, in the open question "Whom would you call a 'true patriot' in the contemporary Russia and in the Russian history?" 'statist' V. Putin leads among contemporaries, and 'statist' Peter the Great - in the country's history (every tenth in both cases ${ }^{5}$ ). While choosing options to end the expression "A real patriot is a person who..." the students preferred both 'presentation' and 'statist' components of 'real patriotism': "honors the history and traditions of the people" (more than 70\%), "performs one's duty in the armed forces", "seeks

5 The percentages are so small because the question was open and no hints were provided. 
to verbally represent his homeland in the most positive way", and "is intolerant to any manifestations of disrespect for one's country and its citizens" (every third).

The majority of students believe that Russia is a country with enormous potential that should not depend on the United States and the West, and all its problems come from the inability of the rulers to rule, their selfish interests, and the lack of 'normal' laws, so after 10-15 years students see Russia as an averagely state. Twothirds fear the threats of social unrest and disorder, every second of mass unemployment, ecological disaster, and economic policy failure, the collapse of science and education system, loss of national culture and religious conflicts. Nevertheless, the majority believes that there is no threat of the country decay or military dictatorship, i.e. students link the problems of Russian society with the state of its administrative apparatus, which is unlikely to guarantee the country strategic positions in the geopolitical context, but students do not fear desovereignization or a radical change of the political regime, thus, every second looks to the future with hope and optimism. In general $27 \%$ of Russians in 2013 stated that probably in fifty years in Russia "engineering, science, arming will be similar to the West, but life will not be the same as in the West", $15 \%$ - that "Russia will become as rich and developed as the Western countries", $11 \%$ - that Russia "will evolve like the great countries of Asia - China and India", and only $10 \%$ feared that "Russia will inevitably face decay and death" (Russia-2063, 2013).

The second dimension of the social mood is constituted by estimates of macro-social context of life in the country together with fears and concerns. The empirical studies of fears usually proceed from Ulrich Beck theory, according to which 'risk societies' are so full of dangers that it is almost impossible to provide a unified definition of risk. Thus, we are to consider risks as both real and potential threats, a system of choices in a risky situation, and reflections of dangers in the public mind (Beck, 1998). In a contemporary risk society massive fears became total and routinized for the official and media discourses 'enrich' the public opinion with the knowledge of the repertoire, the extent and the level of 'normalcy' of a variety of risks. So, sociologists prefer not to speak about the role of different fears in determining destructive forms of behavioron micro and macro level, but to reconstruct the repertoire of fears prevailing in the society as indicators of social wellbeing, to assess the strength, specificity and prevalence of particu- 
lar fears, and to reveal internal, ethnic and geopolitical modes of mass consciousness through the concepts of 'enemies'.

According to the public opinion polls data ${ }^{6}$, since 2008 fears that used to prevail in the Russian society 10-15 years ago (of disintegration of the country, civil war, economic collapse, etc.) have lost their relevance, acuteness, and localization within certain social groups: the majority of Russians experience them (in varying degrees) regardless of gender, age, income, profession, etc.; life and health of family members dominate among the 'objects' of concern. Russians fear most (given only the share of respondents who chose an answer 'experience constant fear') "diseases of children and relatives" (every second), "one's own illness and suffering" (28\%), "poverty, misery" (25\%) and "world war" (27\%); every fifth fears most the death, natural disasters, loss of a job, arbitrary rule and lawlessness; then come fears to lose one's savings and be attacked by criminals, of public humiliation and abuse, AIDS and return to mass repressions (every seventh) (Fears of Russians and threats to the country, 2013).

Figure 1 below shows the distribution of fears of Moscow students according to the results of our representative (by the educational profiles) survey in 2013, although the distribution of answers remains largely the same both earlier and later if we sum up those that are 'very afraid' and 'a little afraid'. The absolute leaders are the threats of terrorist attacks, rampant crime, consequences of the global economic crisis, corruption and lawlessness, i.e. domestic rather than foreign policy issues. Threats to the sovereignty and political stability occupy more modest positions in the list - war conflicts, civil war, ethnic conflicts, revolution/coup scored between $54 \%$ and $66 \%$, although these figures are too high to speak of respondents' positive social mood and confidence in the future. Nevertheless, this does not contradict the above data on the optimistic mood of young people: all threats are constantly mentioned in the political and media discourses, thus, they are perceived as rather routinized and realistic than as actual.

In general, Russians do not fear external threats: approximately every tenth fears the possibility of war with the West, south or southeast neighbors and the loss of state sovereignty or collapse of

6 The distribution of fears depends on the question wording, the set of answers, and the allowable number of choices, however, all such questions let us identifybasic features of respondents' social mood, although experts often criticize the questionnaires used. 


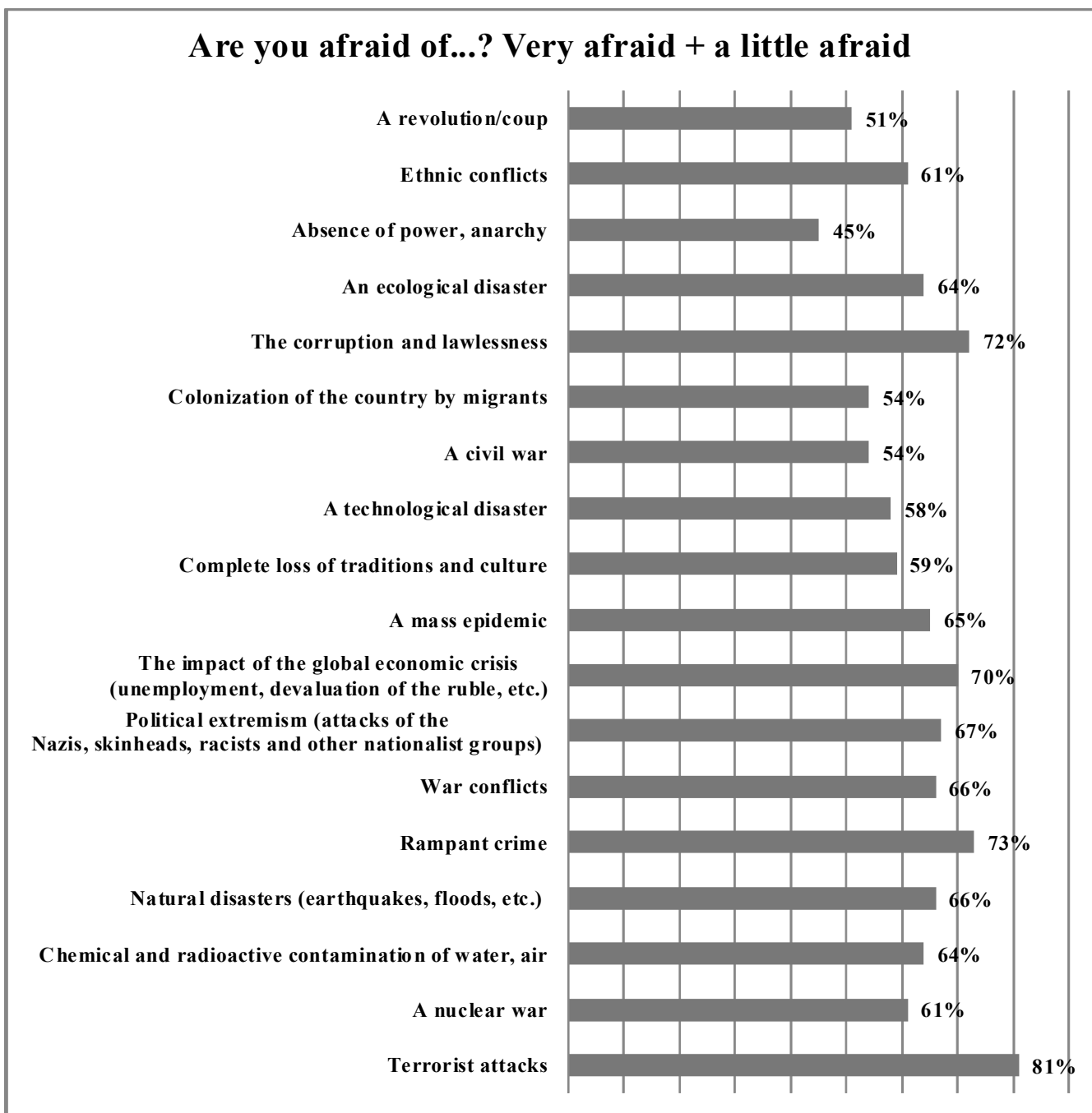

FIGURE 1

the country (Migrants are more frightening than fascists, 2013). Since the early 2000s, public opinion concerns in the foreign policy have strengthened, although there is no country or a group of countries considered a threat by at least half of the respondents. Russians usually name the United States and China first in the list of threats to the country: the former due to the aggravation of Russian-American relations (armed and/or financial intervention of the United States in the life of countries within the scope of the Russian interests); the latter due to the ideological shock caused by 
the relatively sudden appearance of a new superpower on the eastern borders of Russia that (presumably) claims on Russian lands in the Far East (Attitudes of Russians and threats to the country, 2013). Nevertheless, since the beginning of 2000s Russians do not seem to experience "a paranoid fear of the outside world often attributed to them. The majority of Russians... either claim that the country has nothing to fear, or hesitate to say whether it has dangerous enemies. Russians have little interest in the outside world and find new threats and hopes inside the country" (Phantom threats, 2011).

Finally, the third dimension of the social mood - geopolitical awareness, i.e. images of the neighboring countries. This is the most difficult dimension to measure because there are too many countries everybody knows, however, such awareness is usually totally stereotyped. The stereotypes of public opinion about other countries are formed either spontaneously (for instance, as a result of mass tourism), or intentionally, for example, when the state seeks citizens' support in the international arena (to justify aggression or financial and other assistance at taxpayers' expense). In the latter case stereotyping is more evident in the official and media discourses, especially in the countries where the legality of the use of force is based on the public opinion approval.

Unlike the Soviet period, in the last decades and until very recently, the spontaneous mechanism played the key role in shaping the images of other countries in the Russian public opinion due to the political indifference of the population, the dissemination of modern information technologies, which allow organizations and individuals (for example, popular bloggers) to fill social networks with their own 'images' of various countries; and the nowadays freedom to travel all around the world. Most social researchers believe that in Russia, the United States and other geopolitically successful countries (considered to be major players on the world political arena despite serious economic problems and lost military campaigns) public opinion is concerned mainly with domestic problems, and an average citizen rarely (if ever) talks about foreign policy - only under some radical restructuring of world architecture or in crisis situations, which affect his own interests (for instance, if the ministry of foreign affairs does not recommend to travel to the beloved resort). That is why the geopolitical picture is spontaneously formed in the mass consciousness, is different from 
the real situation, is full of stereotypes or mythologized representations, and, thus, is difficult to study.

First, such myths are determined by the public opinion perception of the geopolitical order as either legitimate or wrong. Second, the public opinion is a subject of sharp fluctuations (Parker, 1998), because if a single event does not fit into the stereotypical image of a certain country it can change this image to the opposite. Third, in sociological studies we measure only the 'noise' formed by the media and political technologies, thus, if the images of a country are significantly different in some socio-demographic or ideological 'segments' of society we will not capture the conflicting worldviews and will reveal the most general stereotypes. However, measuring this 'noise' is an important task for assessing the public opinion priorities and forecasting its changes under different foreign policy scenarios.

Already in the late 1990s - early 2000s Russians' perception of the leading world powers was monolithic and based on their key geopolitical characteristics (for example, for China- based on its gigantic size and a growing role in the world politics and economy), while the representations of small countries not playing an important geopolitical role were diverse (for instance, the image of Greece was a bizarre mix of historical facts, myths, and information about Greek goods and resorts). The second important element of other countries images is the historical memory as a basis for assessing the current trends. For instance, "the perception of ??China as a giant fast growing world power makes Russian citizens believe that Russia's relations with this country are more important than with the United States. Besides, the collective memories of the confrontation between the USSR and China in the 1960-1970's, of armed clashes on the borders are still alive and may lead to dangerous phobias" (Kolosov, 2002). The third key element of the geopolitical awareness is the current situation as described in the media and official discourse.

Although I focus on the period before the nowadays worsening of the international situation in general and the status of Russia in particular to describe the images of the neighboring countries in a stable geopolitical framework, to prove the importance of the third element it is enough to refer to the results of the recent research. At the end of $201568 \%$ of Russians declared the bad attitude to the United States (32\% - to the Americans), $60 \%$ - to the European Union, $56 \%$ - to the Ukraine ( $25 \%$ - to the Ukrainians), but not to 
Georgia (32\%) or China (14\%), certainly, due to the lack of ongoing political or military conflicts with the latter two (Monitoring of the Russians' attitudes to other countries, 2015). However the majority believes that it is necessary for Russia to improve relations with the United States, other Western countries, and Ukraine (more than $70 \%)$.

In 2009-2013, the Sociological Laboratory of the Peoples' Friendship University of Russia in cooperation with Beijing Center for Children and Youth Research (China), Serbian Academy of Education, University of Priština in Kosovska Mitrovica - Faculty of Philosophy (Department of Sociology) and Belgrade University (Serbia), and L. N. Gumilyov Eurasian National University (Astana, Kazakhstan) conducted a joint research project to study the student youth worldview in a cross-cultural perspective. In all four countries we conducted a series of surveys on representative student samples in the capitals' universities using basically the same questionnaire, which could be slightly modified to meet the criteria of validity in every country. In 2011 for the first time we added to the Russian questionnaire a new thematic block to reveal the images of neighboring countries. This additional set of questions was purposefully made very small so as not to 'overload' the questionnaire, not to increase the timing for answering the questions, and to find out the basic stereotypes about other countries formed by the political rhetoric and media 'noise' without sensitive topics touched. We studied the image of China in 2011 (testing the new block of questions) and 2013 (to check the stability of the image), the image of Serbia and Kazakhstan in 2012 and 2013 respectively ${ }^{7}$.

Since we started our cross-cultural project with our Chinese colleagues, and the image of China is by definition well established in Russia (the country is often mentioned in the official discourse and media), we decided to begin with identifying the image of China. Certainly, the image of Serbia is less clear in the Russian public opinion for several reasons: small area of the country (and, hence, minor geopolitical role); rare appearance of Serbia in the media; the lack of scientific and journalistic interest in the life of Eastern and Central Europe as a whole, not to mention the image of these countries in the Russian society. Thus, the small questionnaire on China consisted of the following questions: a section on

7 In 2016, we will again 'measure' the images of all three countries to find out whether or not they changed. 
the sources of information about China (seven closed questions in a table form); a request to write the names of three Chinese public figures (an open question); a list of 21 characteristics of a typical Chinese (respondents had to choose five of them); a list of countries to choose those they think most positively about (or/and write their own answer); closed questions to assess respondents' interest to make a trip to China and their perception of Russian-Chinese relations; a set of statements about China development - in each respondents had to express the degree of their agreement; a closed question to assess interest in learning Chinese.

As the results of our surveys show, the majority of students learn about China mainly from the media, probably, that is why among the famous Chinese public figures they named Mao Zedong (more than $70 \%$ ), Confucius (every third), Hu Jintao and Jackie Chan (15\%). Russian students believe that a typical Chinese is hardworking, disciplined collectivist and patriot, nepotistic, easily trained, respecting science and educated, i.e. the image is very positive as well as the image of China - the country with an ever-increasing role in the world (every second) due to the rapid economic growth and successful reforms; every fourth believes that Russia should follow the Chinese example. Nevertheless, there is an obvious ambivalence in the Russian youth estimates of the potential of China: every third believes that the rapid development of China threatens national security of Russia, while more than $40 \%$ are confident that the Russian-Chinese union will play an important role in the global geopolitical structure in the future.

We used the same set of questions to identify the image of Kazakhstan. Certainly, the geopolitical role of Kazakhstan, its media representations and rhetorical articulation in the Russian political discourse, by definition, are much less than in the case of China. However, among other countries of the CIS Kazakhstan is considered the most neutral (or even positive) economic and political partner of Russia according to its dominant representations in the Russian media and statements of the Russian political leaders. The majority of Russian students learn about Kazakhstan mainly from the media, however, unlike China, this source of information turned out to be just as important as communication with Kazakh acquaintances/friends (every second); every third uses the Internet in search of information about Kazakhstan or relevant cultural 'artefacts' (Kazakh cinema, music and literature). 90\% of Russian 
students have never been to Kazakhstan (these figures are similar to the Chinese survey - 85\%).

Among the famous public figures of Kazakhstan $80 \%$ named Nursultan Nazarbayev, all other 'famous' people were named by 5\%-7\%, and among them not only Abay (Kunanbayev)- a poet, philosopher, social activist, and a founder of Kazakh literature, but also Chingiz Aitmatov - a Kyrgyz writer, which indicates a vague identification of national 'affiliation' of key figures of the Soviet period. Russian students believe that a typical Kazakh is nepotistic patriot, collectivist, and hardworking; every fourth consider Kaza$\mathrm{kh}$ freedom loving, peaceful, and disciplined, but at the same time warlike, i.e. the image is rather positive. More than $80 \%$ estimate the Russian-Kazakhstan relations positively: about $14 \%$ believe that the relations between two countries are beneficial for Russia, 70\% that there are more advantages, than 'minuses' for Russia. However, in general, the students are not sure about their perception of Kazakhstan: $60 \%$ admit that they know very little about this country, although they are sure that the Russian-Kazakhstan union will play an important role in the global geopolitical structure in the future, because Kazakhstan chose a successful path of reforms, will play an increasingly important role in the world, is a good neighbor of Russia, and its rapid development does not threaten the national security of Russia.

The questionnaire to identify the image of Serbia was slightly modified and consisted of the following questions: a thematic block on the sources of information about Serbia, but due to the smaller information 'noise' about the country compared to China and Kazakhstan the answers about Serbian movies and songs were removed from the list (unlike the world-wide known Chinese cinema, Serbian movies hardly formed any associations in the Russian public opinion, and even if respondents watched Serbian movies they are unlikely to remember them exactly as such); a request to choose any number of associations with the word 'Serbia' (and/or write one's own answer); a request to write the names of three well-known Serbian public figures (open question); a request to up to 5 out of 21 characteristics of a typical Serb; a list of countries to choose those the respondents think most positively about or write any other country not mentioned (in each survey China was in the list, while Kazakhstan and Serbia were added only in 'their' questionnaires); closed questions to assess respondents' perception of Russian-Serbian relations; a closed question for self-assessing one's 
awareness of Serbia (on the scale from a 'specialist' to an absolute unawareness, which is quite typical for small countries on the map of Europe that looks like a patchwork compared to China); closed questions to assess respondents' interest in learning Serbian language and their intention to make a trip to Serbia.

Again the majority of students learn about Serbia from the media (more than $80 \%$ ) and the Internet (every second), every tenth visited Serbia (this is a big figure taking into account the size of the country, although there can be a simple explanation - probably many tourists pass through Serbia to other destinations). The students estimate their awareness of Serbia as very poor, which reflects the real situation: every third does not know the country and its geographical location; every second has some general idea about Serbia. Such a low awareness determines that the first association with the word 'Serbia' is geographic (country on the Balkan Peninsula), then the most frequently mentioned associations are geopolitical, formed by the dominant media representations of the country as constantly involved in ethno-political conflicts with other countries of the former Yugoslavia, as a homeland to the people kindred to Russians by the Slavic origin and Orthodox faith; every fifth considers Serbia the most friendly European country with a highly patriotic people and a wonderful tourist location with beautiful nature.

Among the famous Serbian public figures students named Slobodan Milošević (19\%), Boris Tadić (13\%), Emir Kusturica (9\%) and Vojislav Koštunica (7\%), i.e. here the differences in the degree of awareness of Serbia and China is obvious for in the latter case the leaders of the list of famous public figures were mentioned by several times more often. Besides, among ten most famous Serbs (named by $1 \%-2 \%$, though often their names were written incorrectly) the students mentioned sportsmen, i.e. they know only those Serbs whose names appear in the Russian media in connection with some political, cultural or sporting events.

Russian students believe that a typical Serb is a patriot, collectivist, a freedom-loving family man, honest and hard-working, both militant and peaceful, educated, disciplined, and loyal realist. Thus, the image is rather positive, but at the same time contradictory, perhaps, due to the general perception of the country in Russia: on one hand, as traditional, agrarian, patriarchal and friendly, on the other hand - as constantly involved in (armed) conflicts. Because of positive associations' prevalence, students either evaluate rela- 
tions between Russia and Serbia as friendly (more than $40 \%$ ), or find it difficult to answer the question (more than $40 \%$ ), while in the next question the majority states that there are more pros than cons for Russia in the relations with Serbia (74\%).

One of the most important questions in all our surveys was the request to choose from the given list of countries those the students think most positively about. As we can see on Figure 2, there are no definite positive 'heroes': approximately every third thinks most positively about England, Japan, France, Germany, and Switzerland, every fifth -about the United States and China. When we added Serbia to the list (together with Spain that had become one of the most popular tourist destinations for Russians - Figure 3), the data did not change radically, and there are still no definite positive 'heroes': approximately every third thinks most positively about England and France, every fourth - about Spain, Japan, Germany, and Switzerland, every fifth - about the United States and China; only every tenth chose Serbia from the list in a thematically focused questionnaire. The situation did not change when we added Kazakhstan to the list (instead of Serbia): approximately every third thinks most positively about England, France and Germany, every fourth - about Japan, Switzerland, and Belorussia, every fifth - about Cuba; only every tenth chose Kazakhstan from the list in a thematically focused questionnaire. However, the data is quite interesting in the comparative perspective for we see that the percentage of those who sympathize the United States and China is decreasing, while the share of those who sympathize Belorussia and Cuba, on the contrary, is increasing.

Certainly, the proposed approach to the identification of the images of neighboring countries is too schematic to let us make wide generalizations, but this approach and questionnaire can serve as a basis for the further development of similar projects, which aim to reveal social representations and stereotypes of public opinion, especially in a cross-cultural perspective. It is unlikely that anyone today would dare to dispute the fact that contemporary sociology, at least for its empirical part, is fond of comparative analysis in the broadest sense of the word: "The importance and utility of comparative research are as old as the discipline itself. In a now famous quote, E. Durkheim insisted that "Comparative sociology is not a particular branch of sociology; it is sociology itself, in so far as it ceases to be purely descriptive and 


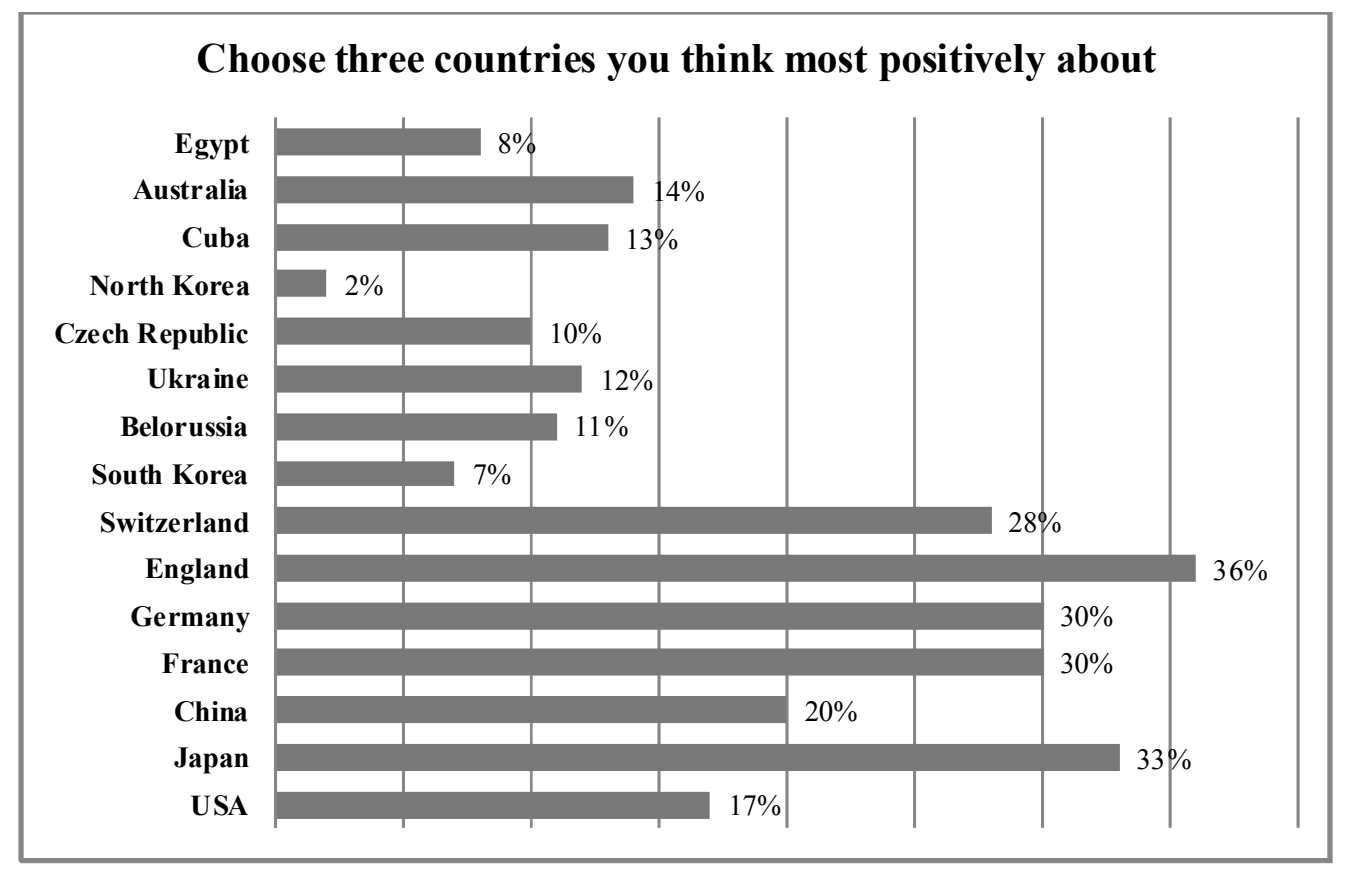

FIGURE 2

aspires to account for facts»" (Mills, van de Bunt, de Bruijn, 2006, p. 619).

To date we conducted only a Russian-Chinese comparative study, but the results are impressing. For instance, the students in both countries learn about other country mainly from the media, and especially the Internet; the majority of students are aware of other country cinema; only 15\% Russian students visited China (9\% of Chinese students - Russia), while more than $40 \%$ would like to do it. As well-known Russian public figures Beijing students named Putin (67\%), Lenin (44\%), Yeltsin (29\%), Stalin (28\%), Gorky (18\%) and Tolstoy (17\%), i.e. they can name more famous Russians than their Russian counterparts - Chinese. The image of a typical Russian in China is more controversial and less positive, than of a typical Chinese in Russia: a patriot, nepotistic, faithful and honest, peaceful and optimistic, but at the same time wild and treacherous, hardworking and lazy. Chinese students consider Russia a country that plays a significant role in the region and in the world, has a powerful army, but did not go through the reforms successfully (compared with China). 


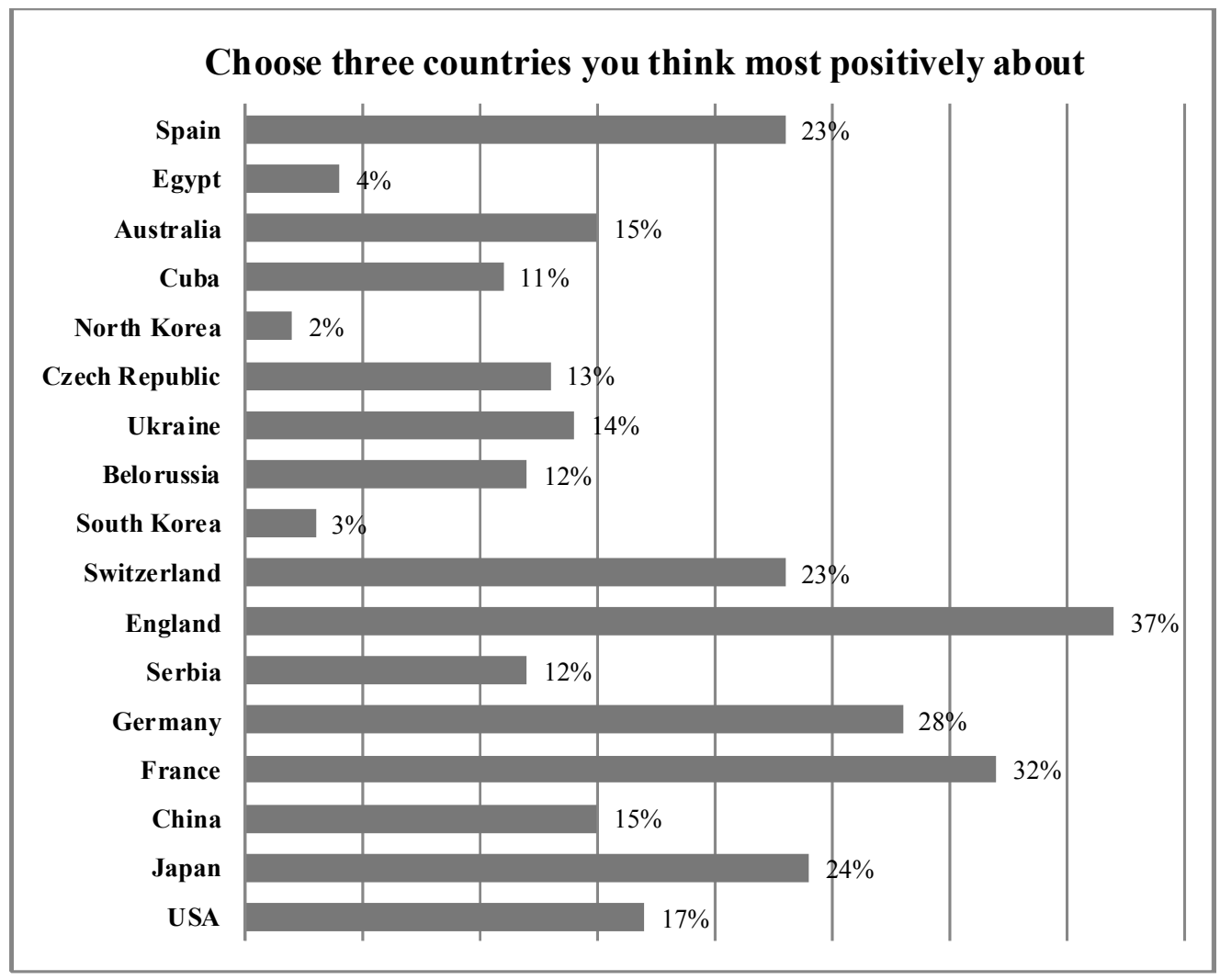

FIGURE 3

In other words, comparative studies of the images of neighboring countries (in cross-cultural and time perspectives) have to become a common type of research rather than an exception causing doubts and suspicions in validity, objectivity, reliability and neutrality in estimates.

REFERENCES Attitudes of Russians and threats to the country (2013). Retrieved from http://www.levada.ru/11-07-2013/ustanovki-rossiyan-i-ugrozy-strane.

Beck U. (1998). World Risk Society. Polity Press.

Dal' V. (1978). Explanatory Dictionary of Russian Language. Moscow, Vol.3.

Emigration of the Putin era: What the Russians want to escape from? (2013). Retrieved from http://www.levada.ru/10-06-2013/emigratsiya-putinskoiepo khi-ot-chego-khotyat-bezhat-rossiyane. 
Fears of Russians and threats to the country (2013). Retrieved from http:// wciom.ru/index.php?id=236\&uid=113634.

Florida, R. (2005) The Flight of the Creative Class. Harper Collins Publishers, New York.

Florida R.L. (2002). The Rise of the Creative Class. And How It's Transforming Work, Leisure and Everyday Life. Basic Books.

Kolosov V. (2002). "Low" and "high" geopolitics. Retrieved from http:// bd.fom.ru/report/map/oz02061904.

Migrants are more frightening than fascists (2013). Retrieved from http:// www.gazeta.ru/social/2013/07/22/5495905.shtml?utm_source=vk-group\& utm_medium=click-news\&utm_campaign=smm.

Mills, M., van de Bunt, G.G., de Bruijn J. (2006). Comparative research: Persistent problems and promising solutions. International Sociology, Vol. 21.

Monitoring of the Russians' attitudes to other countries (2015). Retrieved from http://www.levada.ru/2015/01/01/monitoring-otnosheniya-rossiyan -k-drugim-stranam-sentyabr.

New Russian patriotism: national, statist, or civil (2014). Retrieved from http://wciom.ru/index.php?id=268\&uid=13603.

Parker G. (1998). Geopolitics: Past, Present and Future. London: Pinter Publishers.

Phantom threats: Russians are not prone to the paranoid fear of the outside world (2011). Retrieved from <http://fom.ru/Mir/10097>.

Politics depresses Russians (2013). Retrieved from http://www.levada.ru/ 15-08-2013/politika-nagonyaet-na-rossiyan-tosku.

Russia-2063 (2013) Retrieved from http://www.levada.ru/22-08-2013/ rossiya-2063. 
ИРИНА В. ТРОцУК

РУДН

МосквА

РЕЗИМЕ

СОЦИОЛОШКА СТУДИЈА О СЛИЦИ ОБЛИЖЬИХ ЗЕМАЉА: СТЕРЕОТИПИ РУСКИХ СТУДЕНАТА И ЮИХОВ КОНТЕКСТУАЛНИ ОКВИР

У раду се идентификују три основне димензије друштвеног расположења младих. Прва димензија се формира низом различитих когнитивних, афективних и бихевиоралних оријентација (и патриотски расположење је саставни део овог комплекса). Друга димензија се формира низом проценама макро-социјалног контекста живота у својој земљи. Трећа димензија се састоји од геополитичког свести, тј. слике суседних земаља. Све три димензије су тешко мерљиве због мноштва њихових концептуализацијских оквира и превеликих конотације у основној терминологији. Аутор даје преглед резултата низа истраживања спроведених у периоду 2009-2013. на узорцима анкетираних студената од стране Социолошке лабораторије Руског универзитета пријатељства народа (РУДН) како би показао који подаци могу да се добију уз помоћ квалитативних приступа у 'мерењу' ових димензијапогледа младих на свет и социјалног расположења, нарочито у идентификовању заједничких слика оближњих земаља (на примеру Кине, Казахстана и Србије). Аутор се фокусира на техничке и суштинске детаље у анкетама, а закључује препознавањем неопходности откривања друштвеног представљања и стереотипа јавног мњења у крос-културној и компаративној перспективи.

Кључне речи: Руски студенти, стереотипи, слике, оближње земље, социјално и патриотско расположење, социолошко мерење, анкета, кроскултуролошка и компаративна перспектива, 2009-2013. 